\title{
DOES MANAGERIAL OWNERSHIP AND ISLAMIC CORPORATE SOCIAL RESPONSIBILITY REDUCE TAX AGGRESSIVENESS?
}

\author{
Maya Indriastuti ${ }^{1 *}$, Fudji Sri Mar'ati ${ }^{2}$, Dianing Ratna Wijayani ${ }^{3}$ \\ *Corresponding Author \\ ${ }^{1}$ Doctoral Student of Faculty of Economics and Business, Universitas Diponegoro \& Lecturer at Dept. of Accounting, \\ Faculty of Economics Universitas Islam Sultan Agung, Jalan Raya Kaligawe KM 4, Semarang, Indonesia, \\ maya@unissula.ac.id \\ ${ }^{2}$ Doctoral Student of Faculty of Economics and Business, Universitas Diponegoro \& Lecturer at Accounting Department, \\ STIE AMA, Jalan Diponegoro Nomor 39, Salatiga, Indonesia, fudjisrimarati@ stieama.ac.id \\ ${ }^{3}$ Doctoral Student of Faculty of Economics and Business, Universitas Diponegoro \& Lecturer at Accounting Department, \\ Universitas Muria Kudus Jl. Lkr. Utara Kayuapu Kulon, Bae-Kudus, Indonesia, ratna.wijayani@umk.ac.id
}

\begin{abstract}
This study aims to test empirically the effect of managerial ownership on tax aggressiveness with Islamic corporate social responsibility as the intervening variable. The populations of this study were all entities listed in Jakarta Islamic Index from 2015-2019. 40 entities were obtained by using purposive sampling technique. All data were analyzed by using multiple linear regression analysis and sobel test. The results showed that managerial ownership has a significant positive effect on Islamic corporate social responsibility. In contrast, managerial ownership has a negative and insignificant effect on tax aggressiveness. Furthermore, Islamic corporate social responsibility has a significant negative effect on tax aggressiveness and Islamic Corporate Social Responsibility is able to moderate the effect of managerial ownership on tax aggressiveness.
\end{abstract}

Keywords: Managerial ownership, Islamic corporate social responsibility, tax aggressiveness, Jakarta Islamic Index

Received

October 15, 2020
Revised

October 19, 2020
Accepted

October 2130,2020
Published

October 21, 2020

\section{INTRODUCTION}

Tax aggressiveness is the actions taken by companies to reduce their tax obligations (Dyreng, et al., 2008, 2010; Hanlon and Heitzman, 2010). Usually, companies as corporate taxpayers take advantage of weaknesses contained in tax laws and other regulations. This grey area is used as a gap or regulatory looseness that lies between the practice of planning or calculating permissible and prohibited taxes (Hardeck and Hertl, 2014). The more gaps a company uses to avoid taxes, the company will be more aggressive.

Companies with tax aggressive actions have a higher risk than companies that do not engage in tax aggressive practices (Frank, et al., 2009). This risk is in form of the threat of sanctions or fines. The sanction has an impact on the decline in share prices and the company's reputation. As the result, the company's reputation is not good enough in the eyes of investors (Akhtar, et al., 2019; Tanimura and Okamoto, 2013). On the other hand, company management needs to make company profits small so that the taxes that must be paid are also small. Not only potentially to result losses, the practice of tax aggressiveness also aims to earn profits, such as saving on tax expenditures so that the profits of entrepreneurs are greater. Subsequently, the profit can be used to fund investments which can increase company profits in the future. Meanwhile, for management, tax aggressiveness can increase the compensation received from the owners or shareholders of the company. In fact, there are several factors that can reduce tax aggressiveness, including through managerial ownership and Islamic corporate social responsibility.

Managerial ownership is the shareholder who also acts as the company's owner. The shareholder comes from the management, so that he actively participates in decision making 
(Bebczuk, 2005). Share ownership can motivate managers to improve their performance and prosper shareholders so that they can increase company value while maintaining the company's survival. (Hardinata \& Tjaraka, 2013) added that it can be realized by disclosing social activities and minimizing tax aggressiveness (Dyreng, et al., 2010; Rego \& Wilson, 2012). Chyz and White (2014) believed that the relation between tax avoidance and the existence of agency conflicts is strongest for firms with low levels of CEO monitoring. On the contraty, Hadi \& Mangouting (2014); Jamei (2017); Khan, et al., (2013); Razak \& Mustapha, (2013) showed no relationship between managerial ownership and CSR.

Islamic Corporate Social Responsibility (ICSR) is believed to be an appropriate benchmark for CSR disclosure. According to Arshad, et al., (2012) a body that applies shariabased business is essentially rooted in the philosophy of the Qur'an and Sunnah, so that it becomes the basis for executors when dealing with the environment and society. Al-Qur'an Surat Al-Qashash ayat 77:

"And look for what Allah has bestowed upon you (happiness) of the afterlife, and do not forget your happiness from worldly (enjoyment), and do good (to others) as Allah has done good to you, and do not do anything damage on earth. Surely Allah does not like those who do mischief".

Islam holds accountability which is comparable in all arrangements and fields, between soul and body, between individual and family, between individuals and social, and between a community with another society (Darmawati, 2014). Social responsibility states about obligations industry in order to protect and convey participation to society where the industry is located.

Prior literature shows mixed results in terms of the association between CSR and tax avoidance. For instance, Col and Patel (2016); Lanis and Richardson (2012a); Lin, et al., (2017) find that firms disclose CSR activities to hedge against the reputational risks of taxavoidance practices. In contrast, Hoi, et al., (2013); Huseynov and Klamm, (2012); Lanis and Richardson $(2012,2015)$ showed that company with high CSR disclosure engage in lower level of tax avoidance. Rudyanto \& Pirzada (2020) argued that CSR can moderate between tax avoidance and firm value. Based on the variation of prior studies' findings regard the link between ownership structure, CSR and tax avoidance, this study investigates whether the ICSR disclosure can moderate the association between managerial ownership and tax aggressiveness.

\section{LITERATURE REVIEW}

\section{Agency Theory}

Agency theory describes the relationship between the principal (company owner) and the agent (company management) (Jensen \& Mecking, 1976) which can trigger agency conflicts. The behavior of managers / agents acts only to benefit them by violating the interests of other parties / owners. This happens because the manager has complete information about the company, while the information is not owned by the owner of the company (in this case asymmetric information arises). Asymmetric information and self-serving behavior to managers / agents enable them to make decisions and policies that are less beneficial to the company. It results unhealthy corporate governance because there is no openness from management to disclose the results of their performance to the principal as the owner of the 
company. Agency theory analyzes and seeks solutions to two problems that arise in the relationship between principals and agents.

\section{Sharia Enterprise Theory}

Triyuwono (2015) stated that sharia enterprise theory is a theoretical concept that recognizes accountability not only to the owner of the company but to a wider stakeholder group. Shari'ah enterprise theory states that corporate stakeholders are not only humans and nature around them, but also Allah SWT. God is the last center of responsibility for all activities in the world (Triyuwono, 2015). The link between this concept and Islamic Corporate Social Responsibility is the perspective of resources by the company, as a mandate from God that is inherent in a responsibility. Indriastuti \& Najihah, 2020) argued that corporate social activity is a form of compliance and responsibility of the company owner for his beliefs, in order to maintain and share with the surrounding. It is a way to contribute to the good of all those who need it.

\section{Tax Aggressiveness}

Hoffman (1961) defined tax aggressiveness as "the taxpayer's ability to organize his financial businesses in such a way as to suffer a minimum tax liability. Frank, et al., (2009) claimed that tax aggressiveness is an act of reducing payable tax through a tax planning, whether permitted by the tax regulations or not. Taxes paid by the entity represent transfers of the entity's assets to the government which are deemed as burdensome to the entity. Therefore, the entity has a tendency to avoid / save taxes as efficiently as possible (Dyreng, et al., 2018).

\section{Managerial Ownership}

Managerial ownership is the shareholder who also acts as the owner of the company from the management, so that they actively participate in decision making (Khan, et al., 2013). Share ownership can motivate managers to improve their performance and prosper the shareholders, so that they can increase company value while maintaining the company's survival. Furthermore, (Hardinata \& Tjaraka, 2013) stated that it able to minimize the occurrence of tax aggressiveness.

\section{Islamic Corporate Social Responsibility (ICSR)}

Arshad, et al., 2012) explained that Islamic Corporate Social Responsibility (ICSR) concepts consist of the concept of zakat, justice, benefit, responsibility, and falah (success). The disclosure index used in this study was Islamic Social Reporting (ISR) disclosure index compiled by Othman, et al., (2009). It covers six disclosure themes including; finance and investment, products and services, employees, society, environment, and corporate governance.

\section{Managerial Ownership and Islamic Corporate Social Responsibility}

Managerial ownership can align differences in interests between principals and agents in order to minimize the opportunistic behavior (Jensen \& Mecking, 1976). Managers will strive to improve their performance and prosper the shareholders so that they can create a good image. This has an impact on company value while maintaining the survival of the company (Hardinata \& Tjaraka, 2013). The Islamic corporate social responsibility disclosure is one of the efforts of a manager. Managers do not only care about themselves but also care about the 
social and surrounding environment, which is ultimately a form of responsibility to Allah SWT. The higher the managerial ownership, the higher the level of corporate social responsibility disclosure (Jo \& Harjoto, 2011). First hypothesis:

$\mathrm{H}_{1}$ : Managerial ownership has a positive effect on Islamic corporate social responsibility

\section{Managerial Ownership and Tax Aggressiveness}

Managerial ownership of shares makes management more careful in making decisions (Jensen \& Mecking, 1976), because whatever decisions are made by management, the management will also feel the impact of the decisions. In addition, the management will also bear losses for decisions made if the decisions are not correct. Apart from being careful in making decisions, management will also be more active in fulfilling shareholders' interests and eliminating agency problems. The high level of managerial ownership makes the company more compliant with the applicable tax laws and practices a bit tax. Thus it can balance the interests of both parties when making decisions to set taxes (Chyz and White, 2014). Consistent with (Dyreng, et al., 2010; Rego \& Wilson, 2012). Chyz and White (2014) that managerial ownership can reduce tax aggressiveness. Second hypothesis:

$\mathrm{H}_{2}$ : Managerial ownership has negative effect on tax aggressiveness.

\section{Islamic Corporate Social Responsibility and Tax Aggressiveness}

Islamic corporate social responsibility (ICSR) is a disclosure of social responsibility carried out by companies. It is also a form of responsibility to Allah SWT and stakeholders (Hadi, 2016). The ICSR disclosure is a form of communication between the company, the community and the surrounding environment. It aims to attract public and investor trust that the company does not act a tax aggression. The more disclose ICSR activities of a company, the less tax aggressiveness they take (Alsaadi, 2020). This is in accordance with the sharia enterprise theory. It states that the practice of ICSR disclosure is not only done to create a good response from the community but also as a form of responsibility to Allah SWT. In other words, everything that is done will be accounted for at the end of the day. By this belief, the entity will not carry out tax aggression intentionally or unintentionally, because they know that they are being watched by Allah SWT. Moreover, a positive response from the public can foster good value for entities in the public which not only has an impact on the profit that continues to increase. (Lanis and Richardson, 2012) argued that it also adds blessings to the entity itself. (Hoi, et al., 2013; Huseynov and Klamm, 2012; Lanis and Richardson, 2012b, 2015) showed that companies with high CSR disclosure engage in lower level of tax avoidance. Third hypothesis:

$\mathrm{H}_{3}$ : ICSR has negative effect on tax aggressiveness

Figure 1: Research Model

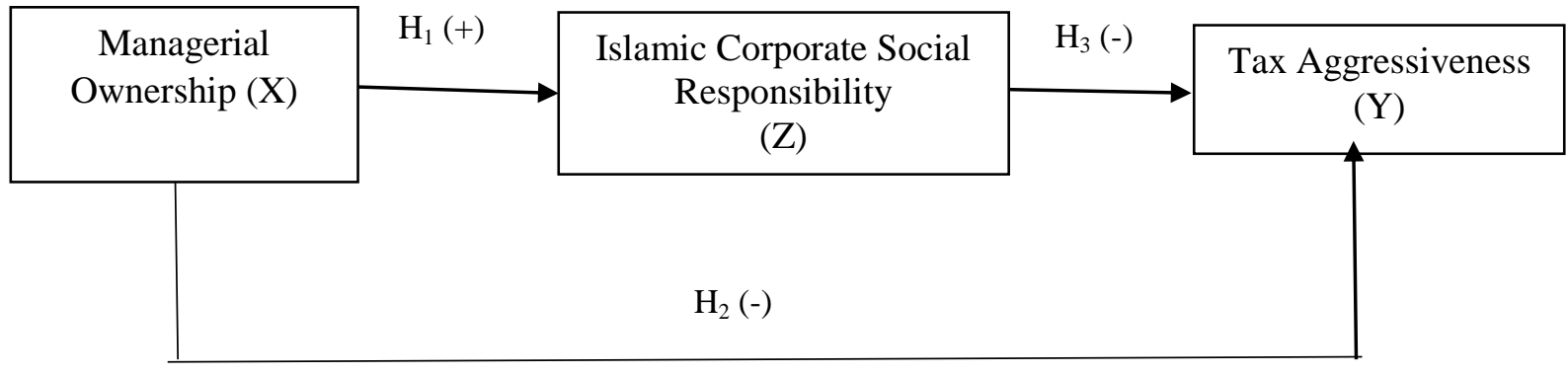




\section{METHOD}

The populations in this research were all entities listed in Jakarta Islamic Index from 2015-2019. The sampling used purposive sampling method with criteria: (1) entities registered in Jakarta Islamic Index during the observation period; and (2) entities that have a complete annual report related to research variables. Based on the criteria, the number of samples during the observation period was 40 entities ( 8 entities x 5 years). The independent variable of this study is managerial ownership, whereas the dependent variables are tax aggressiveness and Islamic corporate social responsibility as an intervening variable. Managerial ownership is the amount of share ownership by the company's managerial compared to the total outstanding shares (Jensen \& Mecking, 1976). Islamic Corporate Social Responsibility (ICSR) is the responsibility of organizations that run their businesses based on sharia on the Qur'an and Sunnah (Arshad, et al., 2012). ICSR measurement used a ratio between the number of ICSR disclosed items and the total number of ICSR items (Arifin dan Wardani, 2016). The ICSR measurement scale used a ratio scale that has an absolute zero and has the same distance. Tax aggressiveness is an entity's move to reduce the payable tax either legally or illegally (Frank, et al., 2009). ETR is used to measure a company's ability in reducing its relative tax payments to profit before tax (Lanis and Richardson, 2012b; Ying, 2011).

The data analysis technique in this research used multiple linear regression analysis and sobel test (Ghozali, 2016). The regression equation is as follows:

$$
\begin{array}{ll}
\text { ICSR } & : \alpha+b_{1} M O+e \\
\text { TA } & : \alpha+b_{1} M O+b_{2} I C S R+e
\end{array}
$$

Information :

ICSR : Islamic Corporate Social Responsibility

TA : Tax Aggressiveness

MO : Managerial Ownership

b1, b2 : Coefficient

$\mathrm{e}_{1}, \mathrm{e}_{2}$ : Error of term

\section{RESULT}

\section{Descriptive Statistic}

The results of descriptive statistical calculations in managerial ownership, Islamic corporate social responsibility, and tax aggressiveness are shown in table 1.

Table 1: Descriptive Statistic

\begin{tabular}{lcrrrr}
\hline & $\mathrm{N}$ & \multicolumn{1}{c}{ Minimal } & \multicolumn{1}{c}{ Maximal } & \multicolumn{1}{c}{ Mean } & \multicolumn{1}{c}{ Deviation Std. } \\
\hline Managerial Ownership & 40 &, 00001 &, 90530 &, 10122 &, 37647 \\
\hline ICSR & 40 &, 26435 &, 56138 &, 32375 &, 17424 \\
\hline Tax Aggressiveness & 40 &,- 49526 &, 72821 &, 11895 &, 37363 \\
\hline
\end{tabular}

Source: SPSS Output (2020)

Managerial ownership variable has the lowest value $=0.00001$; highest value $=0.90530$; mean $=0.10122$ with a standard deviation of 0.37647 . The mean below the standard deviation indicates that the managerial ownership data is unstable (a deviation occurs). ICSR with ICSR DI proxy has the lowest value $=0.26435$; highest value $=0.56138$; mean $=$ 0.32375 with a standard deviation of 0.17424 . The mean above the standard deviation indicates that the ICSR data is stable (no deviation occurs). Tax aggressiveness with ETR 
proxy has the lowest value $=-0.49526$; highest value $=0.72821$; mean $=0.11895$ with standard deviation $=0.37363$. The mean below the standard deviation indicates that the ETR data is unstable (a deviation occurs).

\section{Classic Assumption Test}

A good regression model must fulfil the absence of classic assumption problem. The results of classic assumption test are presented in table 2 .

Table 2: The Results of Classic Assumption Test

\begin{tabular}{|c|c|c|c|c|c|c|c|c|c|}
\hline \multirow[t]{2}{*}{ Model } & \multirow[t]{2}{*}{$\begin{array}{l}\text { Dependent } \\
\text { Variable }\end{array}$} & \multirow[t]{2}{*}{$\begin{array}{c}\text { Independent } \\
\text { Variable }\end{array}$} & \multicolumn{2}{|c|}{ Normality Test } & \multicolumn{2}{|c|}{ Multicollinearity Test } & \multicolumn{2}{|c|}{$\begin{array}{c}\text { Heteroscedasticity } \\
\text { Test } \\
\text { (Glejzer Test) }\end{array}$} & \multirow{2}{*}{$\begin{array}{c}\text { Auto } \\
\text { Correlation } \\
\text { Test } \\
\text { (Run Test) } \\
\text { Sig } \\
\end{array}$} \\
\hline & & & $\mathrm{K}-\mathrm{S}$ & Sig & Tolerance & VIF & $\mathrm{t}$ & Sig & \\
\hline Model 1 & ICSR & $\begin{array}{l}\text { Managerial } \\
\text { Ownership }\end{array}$ & 0.202 & 0.771 & 1,455 & 4.339 & .466 & 0.322 & .146 \\
\hline \multirow[t]{2}{*}{ Model 2} & \multirow{2}{*}{$\begin{array}{c}\text { Tax } \\
\text { Aggressiveness }\end{array}$} & $\begin{array}{l}\text { Managerial } \\
\text { Ownership }\end{array}$ & 0.177 & $\begin{array}{l}0.966 \\
0.642\end{array}$ & 1,662 & 5.911 & .661 & & \multirow[t]{2}{*}{.255} \\
\hline & & ICSR & & & 1,883 & 3.445 & .388 & 0.215 & \\
\hline
\end{tabular}

Source: SPSS Output (2020)

Table 2 shows the results of classic assumptions test for each variable. Kolmogorov Smirnov value shows a significance value of 0.202 and 0.177 . It means that the data is normally distributed. Muticollinearity test results show that all variables have met the multicollinearity criteria with a tolerance value higher than the default standard value for 0.10 and the VIF value showed lower than 10 . Heteroscedasticity test results show a significance value above $5 \%$. It can be interpreted that there is no heteroscedasticity problems in the effect of managerial ownership and ICSR variables on tax aggressiveness. The autocorrelation test results of model 1 and 2 show that run test sig values are .146 and .255. This means that regression models 1 and 2 have no autocorrelation problem because the asym sig value is more than $5 \%$.

\section{Multiple Linear Regression Analysis}

The results of multiple linear regression analysis tests that include the coefficient of determination test results and test results can be seen in table 3 .

Table 3: The Results of Multiple Linier Regression

\begin{tabular}{lcccc}
\hline \multicolumn{1}{c}{ Model } & $\begin{array}{c}\text { Unstandardized } \\
\text { Coefficients }\end{array}$ & $\mathrm{t}$ & sig & Decision \\
\hline 1. Managerial Ownership & 0,275 & 3.866 & 0.000 & $\begin{array}{c}\text { H1 } \\
\text { Accepted }\end{array}$ \\
\hline $\begin{array}{l}\text { Dependent Variable: ICSR } \\
\begin{array}{l}\text { F count = 5.844; sig 0.004 } \\
\text { Adjusted R square = 0.211 }\end{array}\end{array}$ & & & \\
\hline 2. Managerial Ownership & & & & \\
\hline ICSR & $-0,122$ & -0.269 & 0.072 & H2 Rejected \\
\hline
\end{tabular}

Dependent Variable: Tax Aggressiveness

F count $=6.551 ;$ sig 0.002

Adjusted R square $=0.343$

Source: Regression estimation output (2020)

Model 1, managerial ownership variable has $t$ count $=3.866$ and sig $t=0.000<0.05$, which means that managerial ownership has a significant positive effect on ICSR or H1 is accepted. Model 2, the managerial ownership variable has $t$ count $=-0.122$ and sig $t=0.072>0.05$, it 
means that managerial ownership has a negative and insignificant effect on tax aggressiveness or $\mathbf{H 2}$ is rejected. The ICSR variable has $\mathrm{t}$ count $=-2.991$ and $\operatorname{sig} \mathrm{t}=0.001$ $<0.05$, which means that ICSR has a significant negative effect on tax aggressiveness or $\mathbf{H 3}$ is accepted.

\section{Sobel Test}

The sobel test is used to analyze the mediation between exogenous and endogenous variables (Ghozali, 2016). Mediation calculations used a calculation for the sobel test. The test criteria; if the statistical value $>1.96$ and the significance value $<0.05$, it can be an intervening variable. The following is the sobel test result for the ICSR variable which moderates the effect of managerial ownership and tax aggressiveness.

Figure 2: Sobel Test - Managerial Ownership and Tax Aggressiveness through ICSR

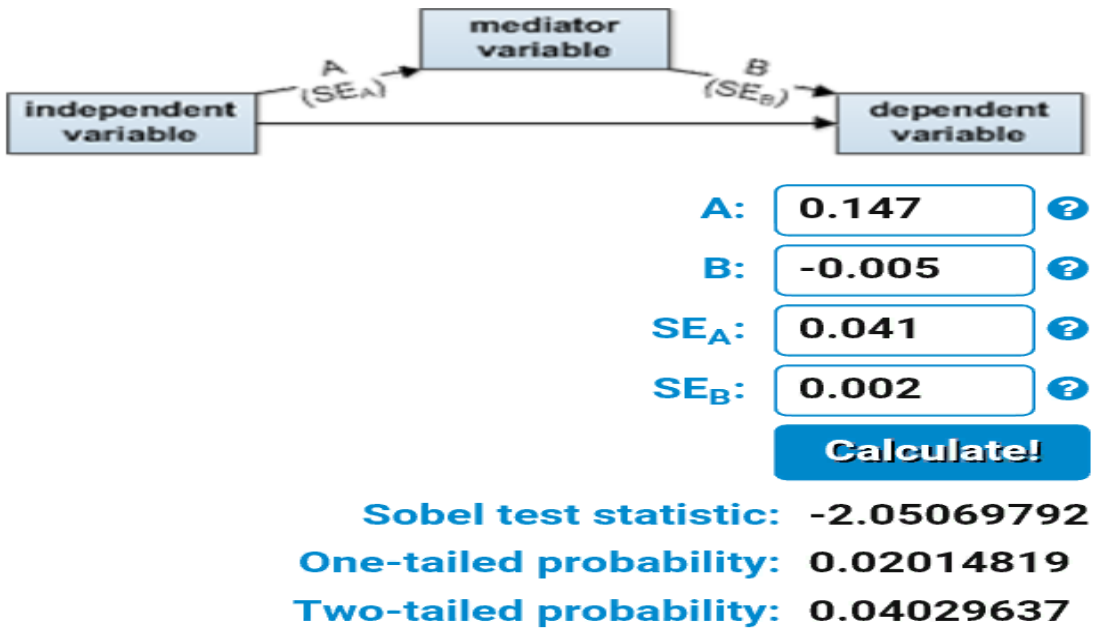

The Sobel test statistic is -2.050 and the two-tailed probability is $0.040<0.05$. It means, ICSR can be an intervening variable between managerial ownership and tax aggressiveness.

\section{DISCUSSION}

\section{Managerial Ownership and Islamic Corporate Social Responsibility}

Managerial ownership has a significant positive effect on ICSR. It means, the more managerial ownership that the manager has, the more ICSR activities will be disclosed. This is because the ICSR disclosure is not only a form of concern for the environment and society but also as a form of responsibility to Allah SWT as a faithful and pious servant of Allah who is able to invite goodness and stay away from His prohibitions (amar ma'ruf nahi mungkar). The principles of sharia in running a business related to CSR are protecting and preserving the environment, trying to alleviate poverty, clean up from something dirty, bring greater benefits, honesty and trust. In the context of sharia enterprise theory, ICSR activities are a need that is not only oriented for the short term, but also for the long term to achieve the pleasure of Allah SWT. Moreover, economic activities are not only related to material aspects, but also the quality of faith in Allah SWT.

The research results are in line with Agustia, et al., 2018; Jo \& Harjoto, 2011) that managerial ownership can increase the number of CSR disclosures. Otherwise, (Khan, et al., 2013; Razak \& Mustapha, 2013) showed no relationship between managerial ownership and CSR. 


\section{Managerial Ownership and Tax Aggressiveness}

Managerial ownership has a negative and insignificant effect on tax aggressiveness. These results indicate that the size of the share ownership owned by the manager has no effect on tax aggressiveness. This is due to the dual role of the managers so that there are two interests that must be fulfilled. In addition to increase bonuses, managers who act as shareholders also want high dividends. Thus, managers will be more careful in making decisions, because whatever decisions are made by management, management will also get the impact of these decisions. In addition, the management will also bear losses if the decisions are not correct. (Jensen \& Mecking, 1976).

Managerial ownership does not significantly affect tax aggressiveness, because share ownership by managers is too small as indicated by a percentage of less than $1 \%$ (Timothy, 2010). Uniamikogbo, et al., (2019) reinforced the findings that ownership structure has a negative and insignificant effect on tax aggressiveness. On the contrary, Chyz and White, (2014); Dyreng, et al., (2010); Halioui, et al., (2016); Rego \& Wilson, (2012) found that corporate governance structure has a significant negative effect on tax aggressiveness.

\section{Islamic Corporate Social Responsibility and Tax Aggressiveness}

Islamic Corporate Social Responsibility has a significant negative effect on tax aggressiveness. The increase of ICSR disclosure can reduce tax aggressiveness. This is because the ICSR obligations carried out by entities registered in Jakarta Islamic Index are in accordance with the sharia enterprise theory. In this theory, the practice of ICSR disclosure is not only conducted to create a good response from the community but also as a form of responsibility to Allah SWT. In other words, everything that is done will be accounted for at the end. With this belief, the entity will not carry out tax aggression intentionally or unintentionally.

The ICSR disclosure is a form of communication between the company, the community, and the surrounding environment in order to attract public and investor trust. It is a proof that the company does not act tax aggression, so that it does not only affect profit but also creates a good reputation in the eyes of the public. Indeed (Lanis and Richardson, 2012) explained that it adds blessings for the entities. This research results are inconsistent with Madarina \& Ardiyanto (2019) who concluded that CSR has positive and significant effect on tax aggressiveness. In contrast, Alsaadi (2020); Luke \& Zulaikah (2016); Huseynov and Klamm (2012); Lanis and Richardson (2012b); Hoi et al. (2013); Lanis and Richardson (2015) found that companies with high CSR disclosure engage in lower level of tax avoidance.

\section{CONCLUSION}

Managerial ownership has a significant positive effect on ICSR, but has a negative and insignificant effect on tax aggressiveness. Islamic corporate social responsibility has a significant negative effect on tax aggressiveness and ICSR is able to moderate the effect of managerial ownership with tax aggressiveness. The limitation of this study is that the ability of the independent variable to explain the dependent variable is still below 50\%, namely $21.1 \%$ and $34.3 \%$. Therefore, the further research can add other variables which can reduce tax aggressiveness (such as: company size, leverage, and others) as well as expanding other research objects. This research contributes to the importance of adopting managerial ownership and ICSR as a company strategy in reducing acts of tax aggression without violating tax laws. Second, the findings of this study can be used by the government as a 
reference for formulating regulations related to tax aggressiveness. Third, for investors it can be used as a guide for making investment-related decisions.

\section{REFERENCES}

Agustia, Dian. Dianawati, Wiwiek and R.A, D. I. (2018). Managerial ownership, corporate social responsibility disclosure and corporate performance. Management of Sustainable Development Sibiu, Romania, 10(2).

Akhtar, S., Akhtar, F., Kose, J. and Wong, S. W. (2019). Multinationals' tax evasion: a financial and governance perspective. Journal of Corporate Finance, 57, 35-62. doi: 10.1016/j.jcorpfin.2017.11.009.

Al-Qur'an Surat Al-Qashash ayat 77.

Alsaadi, A. (2020). Financial-tax reporting conformity, tax avoidance and corporate social responsibility. Journal of Financial Reporting and Accounting, 18(3), 639-659. https://doi.org.proxy.undip.ac.id/10.1108/JFRA-10-2019-0133

Arifin dan Wardani. (2016). Islamic corporate social responsibility disclosure, reputasi, dan kinerja keuangan: studi pada Bank Syariah di Indonesia. Jurnal Akuntansi \& Auditing Indonesia, 20(1), 527-541.

Arshad, Roshayani., Othman, Suaini., Othman, R. (2012). Islamic corporate social responsibility, corporate reputation and performance. International Journal of Social, Behavioral, Education, Economic, Business and Industrial Engineering, 6(4), 643-647.

Bebczuk, R. N. (2005). Corporate Governance and Ownership: Measurement and Impact on Corporate Performance and Dividend Policies in Argentina. Latin American Research Network. Research Network Working Paper R-516.

Chyz, J.A. and White, S. D. (2014). The Association between Agency Conflict and Tax Avoidance: A Direct Approach. Advances in Taxation, Emerald Group Publishing Limited, $\quad 21, \quad$ 107-138. $\quad$ https://doi.org.proxy.undip.ac.id/10.1108/S1058749720140000021007

Col, B.and Patel, S. (2016). Going to haven? Corporate social responsibility and tax avoidance. Journal of Business Ethics, 154(4), 1-18.

Darmawati. (2014). Corporate Social Responsibility dalam Perspektif Islam. Mazahib, 13(2), $125-138$.

Dyreng, S., Hanlon, M. and Maydew, E. L. (2018). When does tax avoidance result in tax uncertainty? The Accounting Review, 94(2). doi:10.2139/ssrn.2374945

Dyreng, S.D., Hanlon, M. and Maydew, E. L. (2008). Long-run corporate tax avoidance. The Accounting Review, 83(1), 61-82.

Dyreng, S.D., Hanlon, M. and Maydew, E. L. (2010). The effects of executives on corporate tax avoidance. The Accounting Review, 85(4), 1163-1189.

Frank, M. M., Lynch, L. J., \& Rego, S. O. (2009). Tax Reporting Aggressiveness and Its Relation to Aggressive Financial Reporting. The Accounting Review, 84, 467496.

Ghozali, I. (2016). The Aplication of Multivariate Analysis using The Program of IBM SPSS 23. Diponegoro University Publisher.

Hadi, A., C. (2016). Corporate Social Responsibility dan Zakat Perusahaan dalam Perspektif Hukum Ekonomi Islam. Ahkam, 16(2), 1-16.

Hadi, J., \& Mangouting, Y. (2014). The effect of ownership structure and board characteristic to tax aggressiveness. Tax \& Accounting Review.

Halioui, K., Abdelaziz, F. B., \& Souhir, N. (2016). Corporate governance, CEO compensation and tax aggressiveness: evidence from American firms listed on the NASDAQ 100. Review of Accounting and Finance, 15, 445-462.

Hanlon, M. and Heitzman, S. (2010). A review of tax research. Journal of Accounting and 
Economics, 50(2-3), 127-178.

Hardeck, I. and Hertl, R. (2014). Consumer reactions to corporate tax strategies: effects on corporate reputation and purchasing behavior. Journal of Business Ethics, 123(2), 309326. doi:10.1007/s10551-013-1843-7

Hardinata, O. S \& Tjaraka, H. (2013). Analisis pengaruh kepemilikan manajerial, kebijakan hutang, dan ukuran perusahaan Terhadap Tax Aggressiveness Pada Perusahaan Manufaktur di Bursa Efek Indonesia Periode Tahun 2008-2010. Jurnal Ekonomi dan Bisnis.

Hoffman, W. H. (1961). The theory of tax planning. The Accounting Review, 36(2), 274-281.

Hoi, C.K., Wu, Q. and Zhang, H. (2013). Is corporate social responsibility (CSR) associated with tax avoidance? Evidence from irresponsible CSR activities. The Accounting Review, 88(6), 2025-2059.

Huseynov, F. and Klamm, B. K. (2012). Tax avoidance, tax management and corporate social responsibility. Journal Lof Corporate Finance, 18(4), 804-827.

Indriastuti, M., \& Najihah, N. (2020). Improving Financial Performance Through Islamic Corporate Social Responsibility and Islamic Corporate Governance. Jurnal Riset Akuntansi dan Bisnis Airlangga, 5(1), 818-833.

Jamei, R. (2017). (2017). Tax Avoidance and Corporate Governance Mechanisms: Evidence from Tehran Stock Exchange. International Journal of Economics and Financial Issue, 7, 638-644.

Jensen, M. C., \& Mecking, W. H. (1976). Theory of the Firm: Managerial Behaviour, Agency Costs and Ownership Structure. Journal of Financial Economics, 3, 305360.

Jo, H.\& Harjoto, M. A. (2011). Corporate Governance and Firm Value: The Impact of Corporate Social Responsibility. Journal of Business Ethics, 103(3), 351-383.

Khan, A., Muttakin, M. B, \& Siddiqui, J. (2013). Corporate Governance and Corporate Social Responsibility Disclosure: Evidence From Emerging Economy. Journal Business Ethics, 114(2), 207-223.

Lanis, R. and Richardson, G. (2012a). Corporate social responsibility and tax aggressiveness: a test of legitimacy theory. Accounting, Auditing and Accountability Journal, 26(1), 75100.

Lanis, R. and Richardson, G. (2012b). Corporate social responsibility and tax aggressiveness: an empirical analysis. Journal of Accounting and Public Policy, 31(1), 86-108.

Lanis, R. and Richardson, G. (2015). Is corporate social responsibility performance associated with tax avoidance? Journal of Business Ethics, 127(2), 1-19.

Lin, K.Z., Cheng, S. and Zhang, F. (2017). Corporate social responsibility, institutional environments, and tax avoidance: evidence from a sub national comparison in China. The International Journal of Accounting, 52(4), 303-318.

Othman, R., Thani, A.M., dan Ghani, E. K. (2009). Determinants of Islamic Social Reporting Among Top Shariah-Approved Companies In Bursa Malaysia. Research Journal of International Studies, 12.

Razak, S. E. A, \& Mustapha, M. (2013). Corporate Social Responsibility Disclosure and Board Structure: Evidence from Malaysia. Jurnal Teknologi, 64(3), 73-80.

Rego, S. O., \& Wilson, R. (2012). Equity risk incentives and corporate tax aggressiveness. Journal of Accounting Research, 50(3), 775-810.

Rudyanto, A., \& Pirzada, K. (2020). The role of sustainability reporting in shareholder perception of tax avoidance. Social Responsibility Journal, March. https://doi.org/10.1108/SRJ-01-2020-0022

Tanimura, J.K. and Okamoto, M. G. (2013). Reputational penalties in Japan: evidence from corporate scandals. Asian Economic Journal, 27(1), 39-57. doi:10.1111/asej.12004

Timothy, Y. C. K. (2010). Effects of Corporate Governance on tax aggressiveness. Hong 
Kong Baptist University.

Triyuwono. (2015). Perspective of Sharia Accounting: Theory and Methods (2nd Ed). Raja Grafindo Persada Company.

Uniamikogbo, Emmanuel; Bennee, Emmanuel and Adeusi, S. A. (2019). Corporate

Governance and Tax Aggressiveness In Nigeria. Ae-Funai Journal Of Accounting, Business And Finance (Fjabaf), 4(1). www.fujabf.org

Ying, Z. (2011). Ownership Structure, Board Characteristics and Tax Aggressiveness. Lingnan University. 